\title{
Hazardous and Toxic Waste (B3) Reduction Program by Reuse GT Battery in PT. PJB UP Muara Tawar
}

\author{
Endrik Purbo Yunastyo ${ }^{1}$, Adhi Eko Apriyanto ${ }^{1}$, Awang Asmoro ${ }^{1}$, \\ Kevin Sanjoyo Gunawan ${ }^{2}$, Totok R. Biyanto ${ }^{2 *}$ \\ ${ }^{1}$ PT. PJB UP Muara Tawar, Muara Tawar, Indonesia \\ ${ }^{2}$ Engineering Physics Department, Institut Teknologi Sepuluh Nopember (ITS), Surabaya, Indonesia.
}

\begin{abstract}
Battery is one of the toxic and hazardous materials. Used batteries are one of hazardous and toxic waste because it contain mercury, manganese, lead, cadmium, nickel and lithium which are harmful to the environment and human health. Battery waste shouldnt be disposed of in public landfills because it will pollute the soil, and groundwater. PT. PJB UP Muara Tawar have various innovative efforts to reduce hazardous and toxic waste generation, one of them with the reuse of ex GT batteries. This is done as commitment PT. PJB UP Muara Tawar maintain nature conservation through reuse battery ex GT. PT. PJB UP Muara Tawar implement some programs such as Marsela, Eco Utility and Fasum Mandiri Energi to reduce hazardous and toxic waste especially the battery produced. The hazardous and toxic waste reduction program by applying the ex-battery reuse shows significant results on waste reduction. This can be seen from the percentage of reuse of ex GT battery which reaches $61.8 \%$ and the cost savings of 5,959 thousand rupiahs during 2013-June 2016.
\end{abstract}

Keywords: battery, hazardous, reuse, toxic, waste

\section{Introduction}

Indonesia Government Regulation No. 101 of 2014 on the Management of Hazardous and Toxic Wastes defines Hazardous and Toxic Substances (B3) as substances, energy, or other components due to their properties, concentrations or quantities, either directly or indirectly pollute and damage the environment, and endanger the environment, health, and the survival of human beings and other living beings [1]. Some materials can further be classified into very flammable, highly flammable, flammable, very toxic, highly toxic, toxic (moderately toxic), harmful, corrosive (corrosive), irritant, dangerous to the environment, carcinogenic, teratogenic, and mutagenic [2].

One of the toxic and hazardous materials around us is battery. Used batteries are one of hazardous and toxic waste because they contain mercury, manganese, lead, cadmium, nickel and lithium which are harmful to the environment and human health. Battery waste shouldnt be disposed of in public landfills because it will pollute the soil, and groundwater. Common handling of waste batteries is reassembled [3] and reuse [4-6]. Various innovation to reduce hazardous and toxic waste generation conducted by PT. PJB UP Muara Tawar, one of them with the reuse of ex GT batteries. This is done as commitment PT. PJB UP Muara Tawar maintain nature conservation through reuse battery ex GT.

\section{Theory}

Hazardous and toxic substances (B3) are components that it can damage the environment, or endanger the environment, health and survival of humans and other living beings. According to the laws and regulations, any activity that produces waste in the form of hazardous and toxic must perform the waste treatment before disposing it. Management of hazardous and toxic waste done by reduction, collection, utilization, transportation and processing and stockpiling of the waste. The waste management activities are as follows

- Hazardous and toxic waste reduction: an activity to reduce the amount and toxic nature of waste.

- Storage of hazardous and toxic waste: temporary storage of hazardous and toxic waste by producer or user.

- Collection of hazardous and toxic wastes: activities to collect hazardous and toxic waste from hazardous and toxic waste producers to reuse for other purpose.

- Transport of hazardous and toxic waste: hazardous and toxic waste removal from producers, collectors, users, to hazardous and toxic waste landfills.

- Utilization of hazardous and toxic waste: recovery, reuse or recycle hazardous and toxic waste to transforming the waste into a product that can be used and safe for the environment and human health.

- Waste treatment hazardous and toxic: process to change the characteristics and composition of hazardous and toxic waste to eliminate or reduce the hazardous nature of hazardous and toxic waste.

- Hazardous and toxic waste landfill: the activity of placing hazardous and toxic waste at a landfill facility. 


\section{Method}

To reduce hazardous and toxic waste especially the battery, PT. PJB UP Muara Tawar implement some programs such as

\section{A. Marsela Program}

The marsela program (community conscious alternative energy) is based on community empowerment by installation of electricity source from solar panel that will be used by the society which is located at boarding school of Al Fatih Bukit Hambalang Sentul Bogor Regency of West Java Province. The use of batteries for storing energy comes from ex GT batteries [7].

\section{B. Eco Utility}

This program is one of the innovations by making hazardous and toxic waste landfill as green building, which utilizes ex GT battery as a storage of electrical energy sourced from solar panels.

\section{Fasum Mandiri Energi}

This program suggest the community to reduce hazardous and toxic waste. By reducing waste, the benefits can be felt directly by the community.

\section{Discussion}

PT. PJB UP Muara Tawar implement various innovation to reduce B3 waste generation from battery ex GT. This is done as a commitment of PT. PJB UP Muara Tawar to maintain nature conservation through reuse battery ex GT.

\subsection{Marsela (Masyarakat Sadar Energi Alternatif)}

PT. PJB UP Muara Tawar continuously strives to realize B3 waste reduction. In 2016, PT. PJB UP Muara Tawar implemented the Marsela program based on community empowerment by making installation of electricity source from solar panels that will be used by people in the boarding school Al Fatih, Bukit Hambalang, Sentul, Bogor District, West Java Province. The Marsela Program intend to optimize alternative energy (sun light) usage. During the day solar panels absorb energy from sun light to be stored in the battery and used at night. This energy is used to turn on the lights, to support activities within the boarding school. Installing these solar panels also provides new knowledge for the students. Marsela program can provide education to the society about alternative energy.

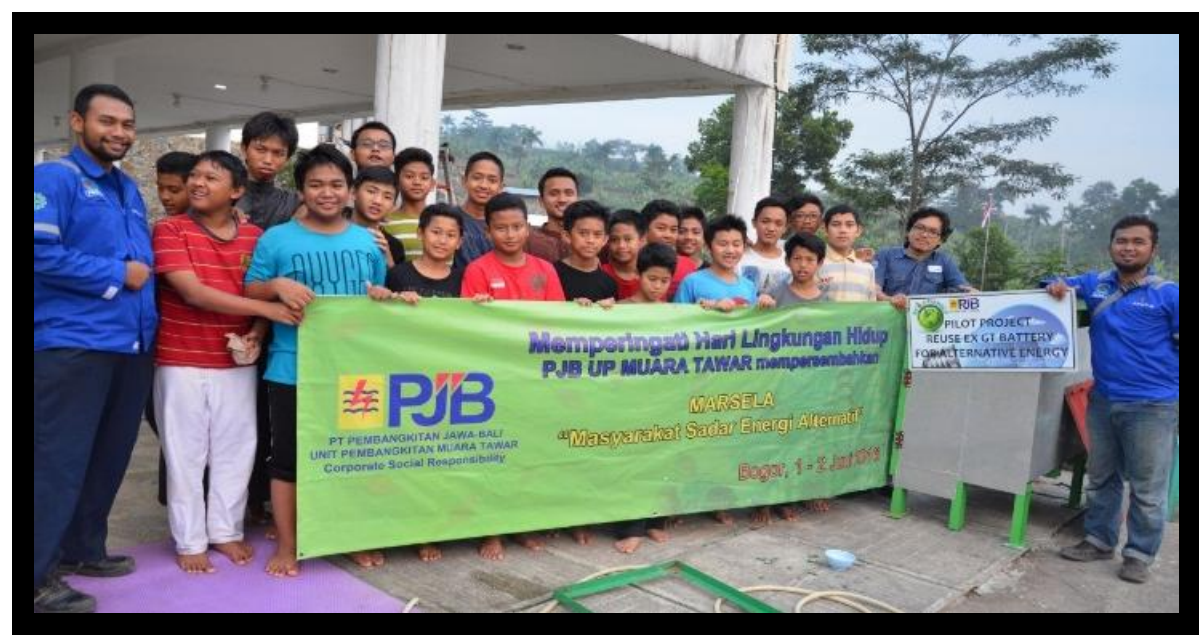

Figure 1. Marsela Program

\subsection{Eco Utility (TPS Limbah B3 Mandiri Energi)}

Eco-utility program is reusing ex GT battery. This program is one of the innovations by making hazardous and toxic landfill as green building, which utilizes ex GT battery as a storage of electrical energy sourced from solar panels. 


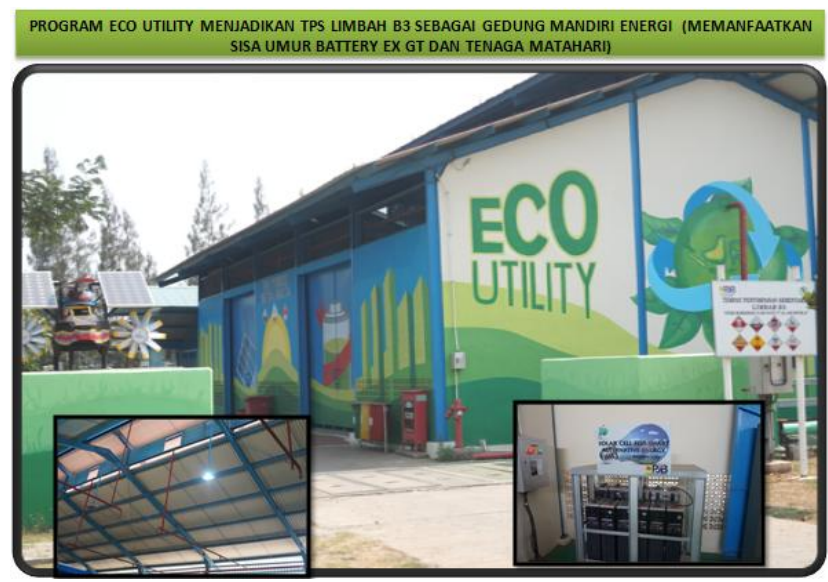

Figure 2. Eco Utility Program

\subsection{Fasum Mandiri Energi}

In addition to Eco Utility and MARSELA programs, PT. PJB UP Muara Tawar also implementing a program to use the remaining battery life of ex GT with the empowerment of the society, namely the Fasum Mandiri Energi program. This program is a commitment of PT. PJB UP Muara Tawar to reduce the hazardous and toxic waste. Some hazardous and toxic waste reduction programs produced by PT. PJB Muara Tawar, which utilize the remaining battery life of ex GT are Eco Green park, Eco Green House, Beacon (Battery Electric Car Charging Station), and CNG Bawean. In Fig. 3 shows the execution of the program that using ex GT battery.

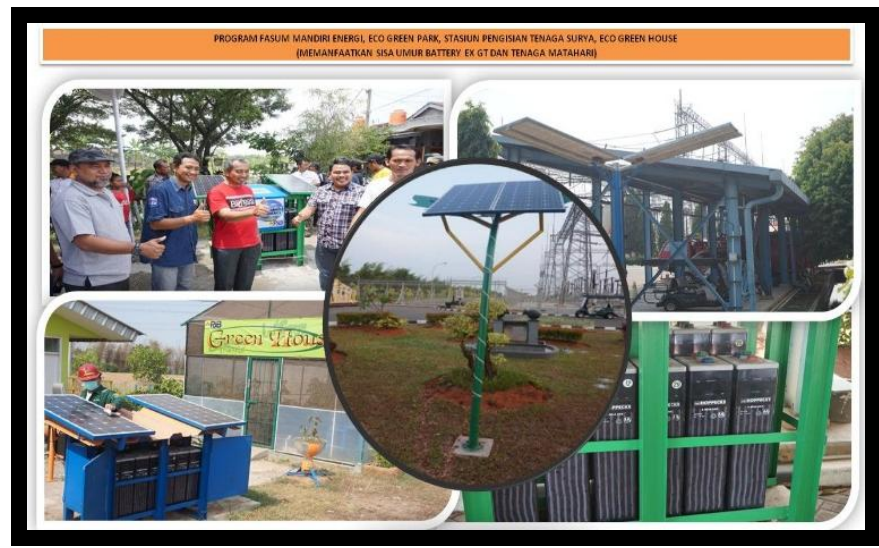

Figure 3. Fasum Mandiri Energi Program

Hazardous and toxic waste reduction reuse battery program that has been done can be seen in Table 1 as follows:

Table 1. Hazardous and Toxic Reuse

\begin{tabular}{|c|c|c|c|c|}
\hline \multicolumn{5}{|c|}{ Hazardous and toxic reduce } \\
\hline year & program & Battery capacity & unit & weight \\
\hline \multirow{2}{*}{2014} & Parking lamp & $600 \mathrm{Ah} / 12 \mathrm{~V} \mathrm{DC}$ & 12 & 0,534 \\
\hline & TOTAL & & & $\mathbf{0 , 5 3 4}$ \\
\hline \multirow{6}{*}{2015} & eco green park & $70 \mathrm{Ah} / 12 \mathrm{VDC}$ & 2 & 0,050 \\
\hline & eco green house & $600 \mathrm{Ah} / 12 \mathrm{~V} \mathrm{DC}$ & 12 & 0,534 \\
\hline & Fasum & $600 \mathrm{Ah} / 12 \mathrm{~V} \mathrm{DC}$ & 12 & 0,534 \\
\hline & eco utility & $600 \mathrm{Ah} / 12 \mathrm{~V} \mathrm{DC}$ & 12 & 0,534 \\
\hline & Beacon (Battery Electric Car Charging Station) & $600 \mathrm{Ah} / 12 \mathrm{~V} \mathrm{DC}$ & 12 & 0,534 \\
\hline & TOTAL & & & 2,186 \\
\hline \multirow{3}{*}{2016} & Marsela & $640 \mathrm{Ah} / \mathrm{Vdc}$ & 16 & 0,712 \\
\hline & CNG Bawean & $640 \mathrm{Ah} / \mathrm{Vdc}$ & 30 & 1,335 \\
\hline & TOTAL & & & 2,047 \\
\hline
\end{tabular}

The tabulation of battery reuse ex GT can be seen in Table 2 follows: 
Table 2. GT Battery Reuse

\begin{tabular}{|l|l|l|l|l|}
\hline Year & Battery production (Ton) & Waste (Ton) & Reuse Battery (Ton) & Percentage (\%)* \\
\hline 2013 & 4,884 & 4,884 & 0,000 & 0,000 \\
\hline 2014 & 0,634 & 0,100 & 0,534 & 84,227 \\
\hline 2015 & 3,536 & 1,350 & 2,186 & 61,821 \\
\hline 2016 & 3,497 & 1,450 & 2,047 & 58,536 \\
\hline
\end{tabular}

PT. PJB UP Muara Tawar successfully reuse ex GT batteries of $61.821 \%$ during 2015 . With the above waste reduction program, it will save the cost of destruction of hazardous and toxic waste. Cost reduction can be seen in Table 3.

Table 3. Reduce Cost

\begin{tabular}{|l|l|l|l|l|l|}
\hline \multirow{2}{*}{ Program } & \multicolumn{2}{|l|}{ Cost reduce (thousand IDR) } & $\begin{array}{l}\text { Cost } \\
\text { (thousand IDR) }\end{array}$ \\
\cline { 2 - 7 } & $\mathbf{2 0 1 3}$ & $\mathbf{2 0 1 4}$ & $\mathbf{2 0 1 5}$ & $\mathbf{2 0 1 6}$ & 668 \\
\hline Parking lamp & - & 668 & - & - & 63 \\
\hline eco green park & - & - & 63 & - & 668 \\
\hline eco green house & - & - & 668 & - & 668 \\
\hline fasum & - & - & 668 & - & 668 \\
\hline eco utility & - & - & 668 & - & 668 \\
\hline $\begin{array}{l}\text { Beacon (Battery Electric Car } \\
\text { Charging Station) }\end{array}$ & - & - & 668 & - & \\
\hline Marsela & & & & \\
\hline CNG Bawean & - & - & - & 890 & 890 \\
\hline TOTAL & - & - & - & 1.669 & 1.669 \\
\end{tabular}

From the above data PT. PJB UP Muara Tawar has made savings about 5.959 thousand IDR during the year 2013-June 2016 period.

\section{Conclusion}

The hazardous and toxic waste reduction program by applying the ex-battery reuse shows significant results on waste reduction. This can be seen from the percentage of reuse of ex GT battery which reaches $61.8 \%$ and the cost savings of 5,959 thousand rupiah during 2013-June 2016.

\section{Acknowledgement}

The authors gratefully thank to PT. PJB UP Muara Tawar - Indonesia for providing the facilities in conducting this research.

\section{Reference}

[1]. Government of Indonesia, Regulation No. 101 Year 2014 on the Management of Hazardous and Toxic Waste, 2014.

[2]. L. Stafford, "Hazardous Substance," in Earth Systems and Environmental Sciences, from Encyclopedia of Energy, Natural Resource, and Environmental Economics, 2013, pp. 98-102.

[3]. E. L. Schneider, W. Kindlein, S. Souza and C. F. Malfatti, "Assessment and reuse of secondary batteries cells," Journal Power Sources, vol. 189 , no. 2, 2009 .

[4]. A. Andrijanovits, H. Hoimoja and D. Vinnikov, "Comparative review of long-term energy storage technologies for renewable energy systems," Electric Engineering, vol. 118, no. 2, 2012.

[5]. F. Diaz-Gonzalez, "A review of energy storage technologies for wind power," Renewable Sustainable Energy, vol. 16, no. 4, p. 2154 , 2012.

[6]. Z. Yang, J. Liu, S. Baskaran, C. H. Imhoff and J. D. Holladay, "Enabling renewable energy and the future grid with advanced electricity storage," Journal of Minerals, Metals, and Materials Society, vol. 62, no. 9, pp. 14-23, 2012.

[7]. S. Tong, T. Fung, M. P. Klein, D. A. Weisbach and J. W. Park, "Demonstration of reusing electric vehicle battery for solar energy storage and demand side management," Journal of Energy Storage, vol. 11, pp. 200-210, 2017. 